\title{
A Study on Decent Work and College Students' Employment
}

\author{
Quanhong Jiang* \\ School of Foreign Languages \\ Beihang University \\ Beijing, China \\ jiangquanhong@buaa.edu.cn
}

\author{
Kejing $\mathrm{He}$ \\ Zhixing College \\ Beihang University \\ Beijing, China \\ 571137618@qq.com
}

\begin{abstract}
Employment and decent work is one of the sustainable development goals proposed by the United Nations. Decent work for college students has become an increasingly prominent problem in China's social and economic development because college students' employment is vital to the students and their families and to development of modern society. Researches have shown that the perception and expectation of decent work in public opinion has an important impact on the employment of college graduates. This paper analyzes the present situation and existing problems of college students' employment, and puts forward some suggestions on promoting college students' employment from the perspective of government, enterprises, universities and individuals.
\end{abstract}

\section{Keywords_-Decent Work; Employment; College Students}

\section{INTRODUCTION}

Unemployment is one of the focal points of modern macroeconomic research, and it's a key indicator of functioning performance of a country or a region[1]. Employment and decent work is put forward by the UN to promote one of 17 goals of sustainable global development[2], which is the biggest livelihood of the people[3].

With the development of the Chinese higher education, the university's enrollment has grown dramatically. Meanwhile, the average of college graduates in 2018 is expected to be 8.2 million people[4]. The employment of college graduates has become an increasingly prominent problem in China's social and economic development because it is of the vital interests of the students and their families[5], which is concerned with the modernization and the harmonious stability of the society[4].

Researches have shown that the perception and expectation of decent labor in public opinion have a much bigger impact on young college graduates[5,6,7,8,9]. From the perspective of decent labor, this paper analyzes the present situation and existing problems of college students' employment, and puts forward some suggestions on promoting college students' employment from the perspective of government, enterprises, universities and individuals.

\section{THEORETICAL BACKGROUND}

The concept of decent work is a process of gradual improvement $[10,11]$. In response to the problems of poverty, unemployment and human rights in many countries in the last century, at the 1995 World Summit on social development, the
International Labor Organization first proposed "Core Labor standards" concept, which aimed to establish and protect the rights of the labor around the world through the form of an international convention. International Labor Organization in 1998 further improved the core labor standards by the declaration of basic principles of labor rights[8,12]. The clear regulation for the four aspects of rights: the freedom of association and the recognition of collective bargaining power, the elimination of all forms of forced labor, the abolition of child labor, and the elimination of employment discrimination[13].

Marx studied the root cause of decent labor in the capitalist mode of production[14]. He pointed out that in the society of exploiting classes, the dignity of laborers is not respected[15]. First of all, labor is not respectable. In the eyes of the capitalists, the workers are just "hands" or machines, or a special kind of capital. Second, the worker who does not work will be more indecent. Third, the laborer is engaged in unseemly labor. The laborer, because of his unseemly labor, is very respectable for not working, or engaging in some "decent" activity. The exploiters, however, feel decent because they do not work, or engage in seemingly respectable activities. The exploiting class society takes the possession of material wealth rather than the nature and size of the wealth created by the society, which measures the value of life, and the underpaid workers are naturally not treated with the dignity of the exploiting class. The laborer does not master the control of production. Therefore, whether the laborer can work, or whether he can work honorably is not to be cared about. Work may be hard, however, the laborers share the joys and sorrows, which is different from making an unseemly labor. For example, the "help" between China's ancient neighbors did not create the GDP, but it solved the problem of the people's survival and development and got the satisfaction of labor. On the contrary, despite the hardship and the respect of society, decent work is still a respectable matter. At the beginning of the founding of Mao Zedong's further development of the Marxist labor theory of production factors, highlight and emphasize the labor is the main body of the laborer, gives workers the subject status of the people's identity and national construction. Through mutual assistance and cooperative collective labor, the workers share the productive information and the fruits of labor. Under the guidance of this kind of guiding ideology, a large number of moral and labor model are appeared. They come from all walks of life, realize the value of labor in their position, and receive recognition and praise from the society. It was not until that 
reform and opening-up that the social transformation of Chinese society on the recognition of decent labor. The measure of decent labor is no longer a guarantee of human rights and a contribution to society, but a pursuit of money. The concept of decent work gradually deviates from the original understanding, which has exerted a great influence on the new generation of workers, especially college students, such as too much pursuit of economic value, unwilling to lower the grassroots level, negative employment mentality, lack of dedication, etc.

The official idea of "decent work" was made at the 87th international labor convention in 1999, and it was defined by Juan Somarvia as a man who had a decent, productive job, in terms of freedom, fairness, security and dignity. This concept has been accepted by scholars both at home and abroad since it was proposed[15].

At the beginning of the 21 st century, scholars put forward the measurement standard of decent labor from different angles. In 2002, Philippe Egger firstly put forward the views of decent labor measurement. Anker(2002)[16] and other scholars[17,18] have established a measure of decent labor, including employment opportunities, unacceptable work, appropriate income and productive work, decent hours, stability and safety ,combination of work and life, fair work conditions, safe working conditions, social security, social dialogue and workplace relations, economic and social background of decent work, 11 kinds. This laid the groundwork for future research, but they did not propose a fixed model to measure it. However, Bonnet (2003)[19] put forward the measurement model of "decent labor index $=($ real value - minimum value $) /($ maximum - minimum value)" in the official journal of the ILO, and selected the measures for the safety of seven individuals. Subsequently, Bescond (2003)[20] and Ghai (2003)[21] proposed more systematic indicators, including the four aspects of rights, employment equality, social security and social dialogue. Their differences were that Bescond were more focused on measuring the "decent labor deficit", whose values of each index were calculated as the indicators of decent labor, while the Dharam Ghai was the average of each subdivided index value. In 2008, the International labor organization proposed 11 measures to measure decent labor: job opportunities, sufficient work income and productive work, appropriate working hours, juggling family and personal life, work that should be abandoned, stability and safety of work, equality of opportunity and treatment in employment, safe working environment, social security, social dialogue and the representation of workers and employers, The economic and social environment of decent labor. This measurement has been widely recognized and popularized in the academic circle.

Although there is a consensus of the dimensions of decent labor in academia, there are very few scholars who have been able to study the particular conditions of China, especially the abundant employment flow trend of the labor supply of college students in the labor market, which indicates that the pursuit of decent labor influences the employment choice of college students.

\section{CURRent Situation AND Problem ANALysis}

\section{A. Employment Intention and Classification Selection}

Employment intention refers to people's expectation and personal preference for the future employment and employment environment based on their understanding of their current situation and their grasp of the real social situation in the process of employment orientation and selection. Factors affecting the employment intention of college students are multidimensional[7]. Zhou(2009)[22] points out that the factors such as income, status, stability, convenience, opportunities and challenges, working conditions and social status are the important factors considered by college students in the process of employment selection. Fan and Wang (2006) also pointed out that the ideal career choice for college students is "three high" (high starting point, high salary, high position), "three points" (work reputation is better, the unit brand is a little bit, the working environment is a little loose)[11].

\section{B. Four Dimensional Analysis of College Students' Decent Labor Deficit}

Decent labor emphasizes the protection of workers' rights and the effective dialogue between workers, employers and governments. Somarvia also illustrates the four strategic goals of a decent workforce in the context of the concept of respectable labor[15]. The International Labor Organization promotes decent work by meeting these four goals. The Dharam Ghai system summarizes the interdependence of the goal of decent labor strategy, which mainly reflects the interdependence of four aspects: employment, social protection, social dialogue and basic rights in work[21].

1) Employment deficit: Full employment is a prerequisite for decent labor, and insufficient employment opportunities and employment difficulties are the most direct manifestation of the employment deficit of college students. Since the great expansion of education in 1999, the total number of college graduates has been increasing. The increase of college graduates is only one aspect of the underemployment of university students. In addition, macroeconomic development is also an important factor in the reduction of employment capacity of college students. In addition, the traditional employment subjects of college graduates, such as stateowned enterprises, public institutions, administrative organs and traditional industries, are faced with difficulties in compiling, reducing and improving the efficiency of staff, as well as digesting and distributing redundant personnel. The demand for college graduates continues to decrease. Another manifestation of the employment deficit is short-term or longterm unemployment. At present, there are more and more students in our country, not in education, employment training. Faced with the severe employment situation, many college students have not found themselves satisfied with their work after graduation, so they neither continue to study for further education nor receive training to find work[23].

2) Right deficit: The right deficit is the phenomenon that college students are deprived of proper rights in employment choice and labor process, employment social exclusion and 
even employment discrimination. It is worth paying attention to female college students' recognition of the gender roles of traditional society, which leads to their blindness, identification and tolerance of gender discrimination in the job market[15]. This attitude regenerates and reinforces the phenomenon of gender discrimination. Some scholars analyzed the market exclusion is primarily the division of employment right in the market segmentation of binary labor[24]. Under the condition of imperfect market competition, the employment social exclusion of college students has been gradually strengthened by the subject and object, which gradually forms the path dependence of the labor market, thus creating the institutionalization of unequal employment opportunities[11]. In this case, due to the phenomenon of legitimate rights, the college students' employment market is still in the buyer's market in general, which leads to the collective unconscious of the college students' deprivation of employment rights, which aggravates the employment right deficit.

3) Social protection deficit: The social protection of workers is designed to give individual rights, seize market opportunities and increase people's productivity. The social protection deficit mainly includes social security, decent working conditions and the lack of protection of vulnerable groups. Social protection is the basic guarantee for workers to enjoy the right of labor, and the main responsibility lies in the government. In the employment process of college students in China, there are not perfect laws, regulations and rules of labor, but more importantly, the enforcement of existing norms is still defective. Many college students enter the informal economy to obtain employment, and there is no corresponding social system protection and government recognition in the process of labor and employment[25]. Hide after the dual labor market barriers to the flow is the difference of two kinds of labor market, social security, in the secondary labor market is often a lack of basic social security or low social security[25]

4) Social dialogue deficit: In the labor relationship, there are differences in the interests of social and economic groups and individuals and the international labor organization believes that the best way to achieve a decent workforce is to have a social dialogue in a way that is more than a multilayered society, to create a balanced and equitable social relationship through social dialogue, to achieve a lot of respect and recognition, and to uphold the rights of the workers[26]. Social dialogue is the voice of the workers in the negotiation and negotiation of salary and welfare in the labor process, which is an important symbol of decent work. The deficit of social dialogue means the lack of the right of discourse in labor negotiation and the passive position in the job market. Due to the imbalance between supply and demand of graduates, there are structural contradictions and fierce job competition[27]. The structural employment contradiction of college graduates, on the one hand, shows the unemployment phenomenon caused by the oversupply of employment area and units. On the other hand, it shows the employment contradiction caused by the mismatch between the class of graduates, the subject, the professional and the actual demand of the job. The employment of college students is in the state of being selected, lacking the mechanism of social dialogue and institutional arrangement[26].

\section{Suggestions for Promoting College Students' EMPLOYMENT AND DECENT WORK}

Under the new normal of China's economic development, informal employment is a new mode of employment for college students. In theory, informal employment should also achieve the goal of decent labor. However, there is always a big gap between reality and desire. The informal employment of college students in China must start from the defect of overcoming decent labor, and promote the realization of informal employment of college students by means of multiple policy measures and system guarantee.

\section{A. Policy Adjustment: Uniform and Affirmative Labor Market}

Government effectiveness is understood as a formal institutional framework for local government support and implementation of market transactions and provides highquality public goods and services. Research on the heterogeneity of employment in the informal employment sector in China shows that the lack of unemployment in the informal sector undermines the self-repair mechanism of the labor market, which in turn makes the employment elasticity coefficient of China's economic growth relatively small, and the policies that rely on economic growth to promote employment have little effect. Therefore, it is necessary to make corresponding policy mechanism adjustment based on the development status of informal employment, to carry out structural reform in the labor market, to establish a unified and equal labor market.

\section{B. Institutional Innovation: Flexible and Fully Covered Social Protection System}

Informal employment of college student is that product of development in free economic market, which is an important force to promote the development of macro economy. However, the lack of decent labor in the informal employment of college students is the most important factor. Therefore, it is necessary to remove the shackles that restrict the informal employment of college students, eliminate institutional social exclusion and promote institutional innovation.

\section{Conceptual Change: Diverse and Individualized Employment Options}

The leading role of concept plays an important role in the informal employment of college students. The change of concept is first reflected in the recognition of informal employment. Informal employment as a new mode of university students' employment, and gradually perfect the related system, college students through informal employment can realize decent work, also can realize own value. The second thing to change is the idea of employment. In the economic development of the new normal and under the background of university students' employment pressure continues to increase, informal employment is the norm in university students' employment, which is communication 
trend of western developed countries after the popularization of higher education.

\section{Capability Enhancement: Education Bidirectional Coupling with Training}

The improvement of college students' employment ability requires the cooperation between schools and enterprises. First of all, we should reform the pattern of personnel training based on employment. In the context of Internet plus, it is necessary to integrate the innovation and entrepreneurship education into the course teaching, and change the education mode of traditional classroom teaching to pay attention to knowledge transfer, and integrate employability training into the whole process of talent cultivation. Secondly, it is necessary to strengthen the training cooperation with the company, combine the characteristics of the informal employment and the actual situation of the college students, elaborate training program and carry out targeted vocational training. Through training, to acquire the skills of irregular employment, to turn into active employment and to actively adapt to the demands of the nonformal employment market, so as to realize the formal labor in the non-formal employment.

\section{REFERENCES}

[1] Q. Chen and J. Yu, "Reconsideration of the correlation between economic growth and unemployment fluctuations," Journal of the Party School of the CPC Central Committee, vol. 2013 (12), pp. 69-73.

[2] The United Nations, Transforming our world: The 2030 Agenda for Sustainable Development, 2015 , https://sustainabledevelopment.un.org/post2015/transformingourworld

[3] J. Xi, The report of the 19th National Congress of the Communist Party of China, the Xinhua News Agency, October 27, 2017.

[4] The Ministry of Education of China, the report of 2018 network teleconference on national college graduates' employment and entrepreneurship, December 2017 , http://www.moe.edu.cn/jyb_xwfb/gzdt_gzdt/moe_1485/201712/t201712 06 320700.html

[5] L. Dai, "How to solve the employment difficulties of college students," Journal of China Statistics, vol. 2017 (2) , pp. 27-29.

[6] J. Li and Y. Sun, "The influence of honorable labor factors on college students' career choice -- taking Anhui Normal University as an example, " Journal of Guide to Business, vol. 2015 (9), pp. 143-145.

[7] Y. Gao and S. Wang, "Analysis on the factors influencing the employment quality of college students in the perspective of a proper labor perspective," Journal of Education Observation, vol. 2017 (9) , pp. 46-48.

[8] D. Luo, "Research on employment intention of college students under the perspective of decent labor," Journal of Overseas and Employment, vol. 2012 (3), pp. 6-7.
[9] L. Deng and T. Tang, "From "find a job" to "decent work": new employment expectation of urban youth -- based on the current situation and problems of youth employment quality in China," Journal of Youth, vol. 2015 (5), pp. 31-35.

[10] H. Li, Joint promotion of the "decent work" of college students, Newspaper of China Labor and Social Security, March 23, 2010

[11] R. Fan and Z. Wang, "Psychological analysis of college students' career choice," Journal of Chinese College Students Employment, vol. 2006 (13), pp. 92-93

[12] Z. Cao, "A survey of decent labor measures for the international labor organization," Journal of Population and Economy, vol. 2011 (6), pp. $57-61$

[13] M. Alzola, "Decent work: the moral status of labor in human resource management," Journal of Business Ethics, vol. 2018 (147), pp. 835-853.

[14] Y. Xu and H. He, "Marx's concept of honorable labor and its contemporary enlightenment -- a discussion on the guarantee of employment in the National People's Congress in 2017," Journal of Hunan First Normal University, vol. 2017 (4) , pp. 42-45.

[15] L. Wu and Q. Le, "Analysis of factors of social exclusion of college students' employment and their correction strategies," Journal of Jiangsu Higher Education, vol. 2012 (2), pp. 110-112.

[16] R. Anker, "People' s Security Surveys: An outline of methodology and concepts," Journal of International Labour Review, vol. 2002 (10) , pp. 309-329.

[17] E. Jonasson, "Informal employment and the role of regional governance," Review of Development Economics, vol. 2011(3), pp. 429-441.

[18] L. Chen, "Understanding informal employment: heterogeneous employment cost, social welfare and stabilization policy," Journal of Yunnan University of Finance and Economics, vol. 2015 (1), pp. 3-13.

[19] F. Bonnet, "A family of decent work indexes," Journal of International Labour Review, 2003, pp. 213-238.

[20] D. Becond, "Seven indicators to measure decent work: An international comparison," Journal of International Labour Review, pp.179-212, 2003.

[21] D. Ghai, "Decent work: Concept and indicators," Journal of International Labour Review, pp. 113-145, 2003.

[22] T. Zhou, "College students' psychological enlightenment to enterprise human resources management," Journal of Modern Enterprise Education, vol. 2009 (9) , pp. 91-92.

[23] J. Su, Job cost, employment ability on the quality of the graduate employment: the empirical analysis based on Mycos employment survey data, vol. 2015 (5), pp. 64-68.

[24] X.L. Yu, "Acceptance and tolerance: The Reproduction of Gender Discrimination against Female Graduates in the Job Market in China, " Journal of Higher Education, vol. 2011 (9) , pp. 76-84.

[25] L. Wu, Y. Ren, and Z. Qiu, "A Study on the Undergraduates' Decent Work Deficit and its Developmental Strategies," Journal of Exploring Education Development, vol. 2015 (19) , pp. 27-33.

[26] L. He, Income distribution, social structure, and lewis turning point, vol. 2018 (1), pp. 61-67.

[27] L. Dai, "The research progress and review of the domestic respectable labor research," Journal of Liaoning Administration Institute, vol.2010(6), pp. 62-63. 